\section{International Scientific Journal Theoretical \& Applied Science}
p-ISSN: $2308-4944$ (print)
e-ISSN: 2409-0085 (online)
Year: 2016
Issue: 11
Volume: 43
Published: $30.11 .2016 \quad$ http://T-Science.org

SECTION 9. Chemistry and chemical technology.
Sabir Ahmad Mammadov

Doctor in Chemistry, Professor, Head of Laboratory, Institute of Chemistry of Additives,

Azerbaijan National Academy of Sciences, Azerbaijan sabir.mamedov.39@mail.ru

Sevgili Ismayil Mammadova

$\mathrm{PhD}$ in Chemistry, doctorant, Institute of Chemistry of Additives,

Azerbaijan National Academy of Sciences, Azerbaijan alximikseva@rambler.ru

Nina Petrovna Ladokhina PhD in Chemistry, Assistant professor, Leadinq Scientific Researcher, Institute of Chemistry of Additives, Azerbaijan National Academy of Sciences, Azerbaijan nina62_62@mail.ru

\section{Shefa Kazim Kazimzade} aspirant,

Institute of Chemistry of Additives, Azerbaijan National Academy of Sciences, Azerbaijan

Isa Shahruddin Huseinov $\mathrm{PhD}$ in Chemistry, Leading Scientific Researcher, Institute of Chemistry of Additives,

Azerbaijan National Academy of Sciences, Azerbaijan

\title{
PROPERTIES AND SYNTHESIS OF ALKOXY - AND AMINOMETHYLENE DERIVATIVE GUANIDINE SULFAMATES AND THEIR HETEROCYCLIZATION
}

Abstract: The alkoxylation and aminomethylation reactions of guanidine sulfamates were studied. It is found that ternary guanidine sulfamates reaction with alcohols and amines in the presence of formaldehyde is terminated with a high yield. Compounds obtained as dipolars are easily heterocyclisize with polarophiles forming functionally substituted pyrimidines. Synthesized compounds are studied as biocides by Hansch's method. It was found that regardless of the heterocyclic fragment content have high bactericidal properties.

Key words: Alkoxymethyl, aminomethyl, guanidine sulfamate, polarophil, heterocyclization, bactericide

Language: English

Citation: Mammadov SA, Mammadova SI, Ladokhina NP, Kazimzade SK, Huseinov IS (2016) PROPERTIES AND SYNTHESIS OF ALKOXY- AND AMINOMETHYLENE DERIVATIVE GUANIDINE SULFAMATES AND THEIR HETEROCYCLIZATION. ISJ Theoretical \& Applied Science, 11 (43): 77-84.

Soi: http://s-o-i.org/1.1/TAS-11-43-15 Doi: crossef http://dx.doi.org/10.15863/TAS.2016.11.43.15

\section{UDC 547.541.521.621}

\section{Introduction}

Guanidines are basic synthons for synthesis of widely used pyrimidines which are structural basis of alkaloids, vitamins, ferments and coenzymes, nucleic acids. Hetarylsulfamides are widely used in preparation of many medical preparations and biocides. Production of functionally-substituted derivatives of pyrimidinesulfamides is required to intensify their biocide and medical effect. In direct introduction of functional groups into pyrimidine fragment results in definite difficulties. That's why synthesis of new dipolar synthons has high theoretical and practical value.

Considering high application value of guanidine sulamides, the synthesis of them was widely studied. The main obtaining method is reaction of arylsulfochlorides with guanidine and with their $\mathrm{N}$ substituted derivatives [1-4]. 


\begin{tabular}{|c|c|c|c|c|c|c|}
\hline Impact Factor: & $\begin{array}{l}\text { ISRA (India) } \\
\text { ISI (Dubai, UAB } \\
\text { GIF (Australia) } \\
\text { JIF }\end{array}$ & $\begin{array}{r}=1.344 \\
=0.829 \\
=0.564 \\
=1.500\end{array}$ & $\begin{array}{l}\text { SIS (USA) } \\
\text { PИHЦ (Russia) } \\
\text { ESJI (KZ) } \\
\text { SJIF (Morocco) }\end{array}$ & $\begin{array}{l}=0.912 \\
=0.234 \\
=1.042 \\
=2.031\end{array}$ & $\begin{array}{l}\text { ICV (Poland) } \\
\text { PIF (India) } \\
\text { IBI (India) }\end{array}$ & $\begin{array}{l}=6.630 \\
=1.940 \\
=4.260\end{array}$ \\
\hline
\end{tabular}

Many works are also conducted [5, 6] on synthesis of guanidinesulfamides by non-standard method in which reaction of $\mathrm{N}$ sulfonyltrifluorosulfonimide with urea or with dicyclohexylcarbodiimide.
According to literature data $[6,7]$, reaction of arylsulfochlorides with guanidine leads to monosubstituted derivatives which are in tautomeric state:<smiles>[R]S(=O)(=O)NC(=N)[R]#C</smiles><smiles></smiles>

Synthesis of N-functionally substituted derivatives of sulfanylguanidines and use of them as synthons for synthesis of substituted pyridinesulfamides are very promising. One of such directions - three-component reaction of guanidinesulfamides with amines and alcohols with paraform.

The data on synthesis of sulfamides using threecomponent reaction of sulfamides with compounds which have active hydrofen in the presence of paraform or keton also exists [8-10].

\section{Experimental part}

PMR-spectra of some synthesized sulfamides were recorded on spectrophotometer «Tesla-467» with operating frequency of $90 \mathrm{MHz}$, IR-spectra - on «NicoletIS-10».

N-3-Alkoxyand aminomethyleneguanidinesulfamides (Ia-g). General technique. $0.1 \mathrm{~mol}$ of guanidinesulfamide, $0.1 \mathrm{~mol}$ of paraform and butyl (or amyl) alcohol or amino compound were dissolved in $50 \mathrm{ml}$ of benzene or toluene. The mixture was boiled till complete extraction of water in Dean-Stark trap. Then 20-30 $\mathrm{ml}$ of hexane was added. Obtained crystals were filtered and crystallized from ethanol.

Physical-chemical properties of compounds are shown in table 1 .

Table 1

Physical-chemical properties of $\mathrm{N}$-alkoxy- and aminomethyl derivatives of guanadinesulfamides (Ia-g).

\begin{tabular}{|c|c|c|c|c|c|}
\hline \multirow{2}{*}{$\begin{array}{l}\text { Cipher of } \\
\text { compounds }\end{array}$} & \multirow{2}{*}{$\begin{array}{c}\text { Yield, } \\
\%\end{array}$} & \multirow[t]{2}{*}{$\mathrm{T}_{\text {melt. }},{ }^{0} \mathrm{C}$} & \multirow[t]{2}{*}{ Chemical formula } & \multicolumn{2}{|c|}{$\underset{\text { calculated, }}{\text { Found }}$} \\
\hline & & & & $\mathrm{N}$ & $S$ \\
\hline 1 & 2 & 3 & 4 & 5 & 6 \\
\hline I a & 74.8 & $310-312$ & $\mathrm{C}_{13} \mathrm{H}_{21} \mathrm{~N}_{3} \mathrm{O}_{3} \mathrm{~S}$ & $\frac{14.51}{14.09}$ & $\frac{10.97}{10.70}$ \\
\hline $\mathrm{I} b$ & 71.3 & $238-240$ & $\mathrm{C}_{14} \mathrm{H}_{23} \mathrm{~N}_{3} \mathrm{O}_{3} \mathrm{~S}$ & $\frac{13.68}{13.46}$ & $\frac{10.46}{10.23}$ \\
\hline I c & 72.1 & $227-229$ & $\mathrm{C}_{13} \mathrm{H}_{21} \mathrm{~N}_{3} \mathrm{O}_{3} \mathrm{~S}$ & $\frac{14.42}{14.09}$ & $\frac{10.39}{10.70}$ \\
\hline I d & 78.9 & $168-170$ & $\mathrm{C}_{13} \mathrm{H}_{21} \mathrm{~N}_{4} \mathrm{O}_{2} \mathrm{~S}$ & $\frac{19.23}{18.90}$ & $\frac{10.93}{10.77}$ \\
\hline I e & 79.5 & $150-153$ & $\mathrm{C}_{13} \mathrm{H}_{20} \mathrm{~N}_{4} \mathrm{O}_{2} \mathrm{~S}$ & $\frac{19.36}{18.97}$ & $\frac{11.14}{10.81}$ \\
\hline If & 70.4 & $65-67$ & $\mathrm{C}_{17} \mathrm{H}_{30} \mathrm{~N}_{4} \mathrm{O}_{2} \mathrm{~S}$ & $\frac{16.22}{15.89}$ & $\frac{9.39}{9.06}$ \\
\hline Ig & 58.7 & $209-212$ & $\mathrm{C}_{18} \mathrm{H}_{21} \mathrm{~N}_{5} \mathrm{O}_{3} \mathrm{~S}$ & $\frac{18.51}{18.14}$ & $\frac{8.49}{8.27}$ \\
\hline
\end{tabular}

Functionally substituted pyrimidines(IIa, b).General technique. $20 \mathrm{~mol}$ of compounds (Ia) or (Id) and $22 \mathrm{~mol}$ of acetylaceton were dissolved in 20 $\mathrm{ml}$ of ethanol. 10 drops of $0.1 \mathrm{~N}$ solution $\mathrm{NaOH}$ were added into ethyl alcohol. The mixture was boiled 1,5 -2 hours, cooled, precipitated crystals were filtered off and crystallized from ethanol.
3,4-Diphenyl-5-butylamino-(4methylphenylsulfonyl) pyrimidine (IIc). Synthesis method is similar to obtaining method of pyrimidines (IIa, b) with the difference that 3butylaminomethyleneguanidinesulfamide (Ia) and benzoin were taken.

3-Amyloxy- orbutylamino-4-methyl-(4methylsulfonyl) pyrimide-5-ons (IId, e). 


\begin{tabular}{|c|c|c|c|c|c|c|}
\hline Impact Factor: & $\begin{array}{l}\text { ISRA (India) } \\
\text { ISI (Dubai, UAF } \\
\text { GIF (Australia) } \\
\text { JIF }\end{array}$ & $\begin{array}{l}=1.344 \\
=0.829 \\
=0.564 \\
=1.500\end{array}$ & $\begin{array}{l}\text { SIS (USA) } \\
\text { PИНЦ (Russia) } \\
\text { ESJI (KZ) } \\
\text { SJIF (Morocco) }\end{array}$ & $\begin{array}{l}=0.912 \\
=0.234 \\
=1.042 \\
=\mathbf{2 . 0 3 1}\end{array}$ & $\begin{array}{l}\text { ICV (Poland) } \\
\text { PIF (India) } \\
\text { IBI (India) }\end{array}$ & $\begin{array}{l}=6.630 \\
=1.940 \\
=4.260\end{array}$ \\
\hline
\end{tabular}

Synthesis method is similar to obtaining method of (IIa, b). However, for reaction compounds (Ia) and (Ib), and ethyl alcohol of acetacetic acid were taken, morpholinium was used as a base.
Physical-chemical properties of compounds are shown in table2.

Physical-chemical properties of derivatives of pyrimidines (IIa-e).

\begin{tabular}{|c|c|c|c|c|c|}
\hline \multirow{2}{*}{$\begin{array}{l}\text { Cipher of } \\
\text { compounds. }\end{array}$} & \multirow{2}{*}{$\begin{array}{c}\text { Yield, } \\
\%\end{array}$} & \multirow{2}{*}{$\mathrm{T}_{\text {melt. }},{ }^{0} \mathrm{C}$} & \multirow{2}{*}{ Chemical formula } & \multicolumn{2}{|c|}{ calculated, $\%$} \\
\hline & & & & $\mathrm{N}$ & S \\
\hline 1 & 2 & 3 & 4 & 5 & 6 \\
\hline II a & 71.2 & $250-252$ & $\mathrm{C}_{19} \mathrm{H}_{25} \mathrm{~N}_{3} \mathrm{O}_{4} \mathrm{~S}$ & $\frac{11.09}{10.77}$ & $\frac{8.48}{8.19}$ \\
\hline II b & 74.3 & $198-200$ & $\mathrm{C}_{18} \mathrm{H}_{23} \mathrm{~N}_{4} \mathrm{O}_{3} \mathrm{~S}$ & $\frac{15.61}{14.98}$ & $\begin{array}{l}8.92 \\
8.54 \\
\end{array}$ \\
\hline II c & 69.6 & $195-197$ & $\mathrm{C}_{27} \mathrm{H}_{27} \mathrm{~N}_{4} \mathrm{O}_{2} \mathrm{~S}$ & $\frac{12.23}{11.92}$ & $\frac{7.29}{6.80}$ \\
\hline II d & 68.9 & $320-322$ & $\mathrm{C}_{17} \mathrm{H}_{22} \mathrm{~N}_{3} \mathrm{O}_{4} \mathrm{~S}$ & $\frac{12.21}{11.57}$ & $\frac{9.12}{8.79}$ \\
\hline $\mathrm{II} \mathrm{e}$ & 70.2 & $208-210$ & $\mathrm{C}_{17} \mathrm{H}_{24} \mathrm{~N}_{4} \mathrm{O}_{3} \mathrm{~S}$ & $\frac{12.46}{12.03}$ & $\frac{9.32}{9.14}$ \\
\hline
\end{tabular}

\section{Results and discussion}

We studied the reaction of guanadinesulfamides with amines and alcohols in the presence of paraform:

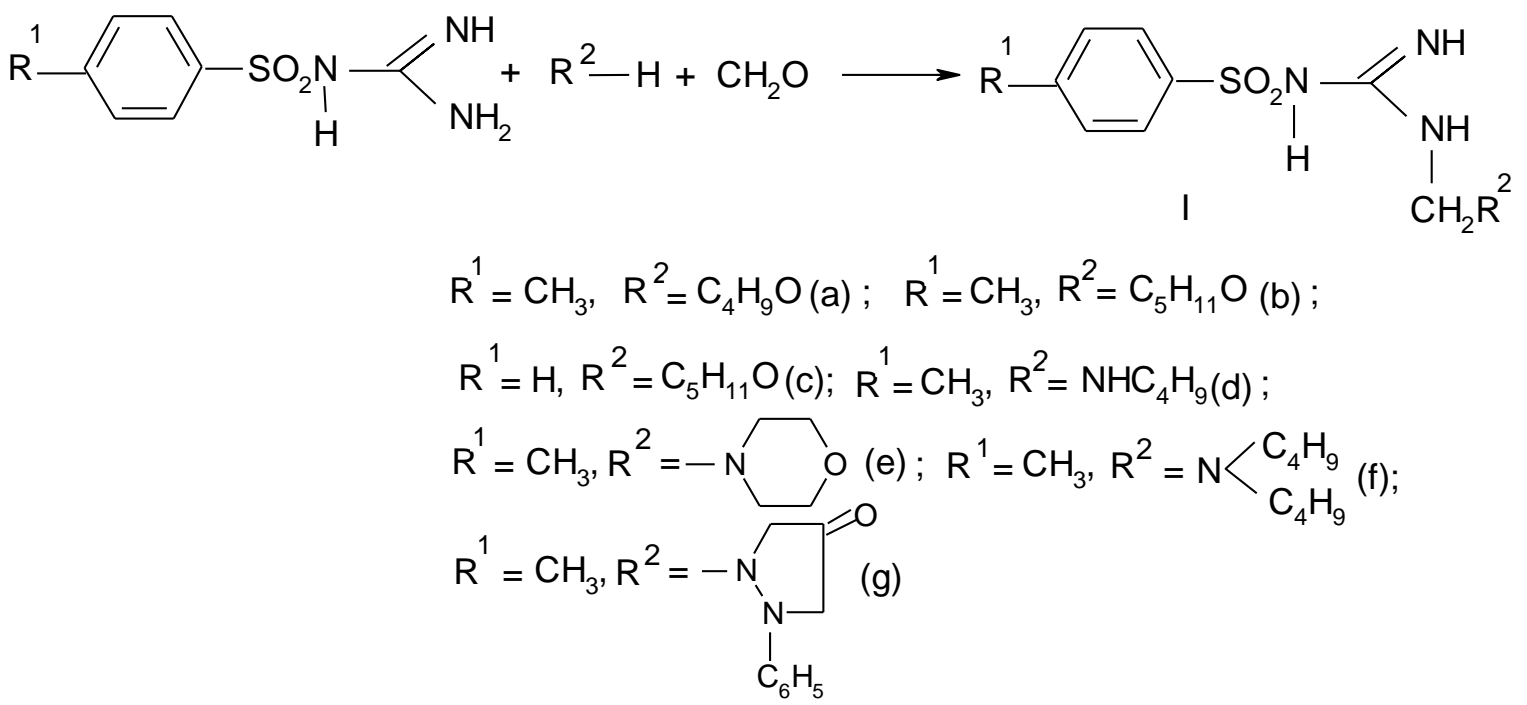

In PMR-spectra (fig.1) of 3-Nbutylaminomethylene-4methylohenylsulfanylguanadine (compound Id) methyl protons of n-toluene appear in $1.0 \mathrm{ppm}$. Methyl and methylene protons of $\mathrm{NC}_{4} \mathrm{H}_{9}$ appear in 2.3 and $3.8 \mathrm{ppm}$. Proton of $\mathrm{NHC}_{4} \mathrm{H}_{9}$-group is in $50 \mathrm{ppm}$, proton of amino group $\mathrm{NHCH}_{2}$ appears in 5.8 ppm under the effect of methylene group, but proton of imino group is in $6.8 \mathrm{ppm}$. Proton of amino group

Table 2 


\begin{tabular}{|c|c|c|c|c|c|c|}
\hline Impact Factor: & $\begin{array}{l}\text { ISRA (India) } \\
\text { ISI (Dubai, UAE } \\
\text { GIF (Australia) } \\
\text { JIF }\end{array}$ & $\begin{array}{l}=1.344 \\
=0.829 \\
=0.564 \\
=1.500\end{array}$ & $\begin{array}{l}\text { SIS (USA) } \\
\text { PИНЦ (Russia) } \\
\text { ESJI (KZ) } \\
\text { SJIF (Morocco) }\end{array}$ & $\begin{array}{l}=0.912 \\
=0.234 \\
=1.042 \\
=2.031\end{array}$ & $\begin{array}{l}\text { ICV (Poland) } \\
\text { PIF (India) } \\
\text { IBI (India) }\end{array}$ & $\begin{array}{l}=6.630 \\
=1.940 \\
=4.260\end{array}$ \\
\hline
\end{tabular}

As is known, more promising way of synthesizing hetarylsulfamides is 1,3-dipolar connection to dipolarophilic compounds. This reaction is a general synthesis method of heterocyclic compounds. Some types of molecules (azides, nitriles, amides, guanadines and others), which have resonant (or activated) structure andeven one element which is characterized by the presence of opposite charges in 1,3-position, are inclined to 1,3-dipolar synchronous additions.

In synthesized compounds I - VII, except sulfamide group, alkoxy- and amino methyl groups are in position 3. Presence of electrophilic sulfamide and electron donor amino group leads to increase of molecule intensity, which strongly influences on activation value (especially methylene group) and on ring closure in synchronous reactions. That's why synthesized compounds enter into heterocyclization reaction with polarophiles. During heterocyclization of compound Ia and Id with acetylacetone in the presence of alkali or morpholine substituted pyrimidines are formed:<smiles>[R]CNC(=N)N(Nc1nc([R])c(C)c(C(C)=O)n1)OS(=O)(=O)c1ccccc1</smiles>

$\mathrm{R}=\mathrm{OC}_{5} \mathrm{H}_{11}(\mathrm{a}) ; \mathrm{NHC}_{4} \mathrm{H}_{9}$ (b)

Heterocyclization of compound Id with benzoin results in 3,4-diphenyl-5-butylamino-4methylsulfonylamidopyrimidine:

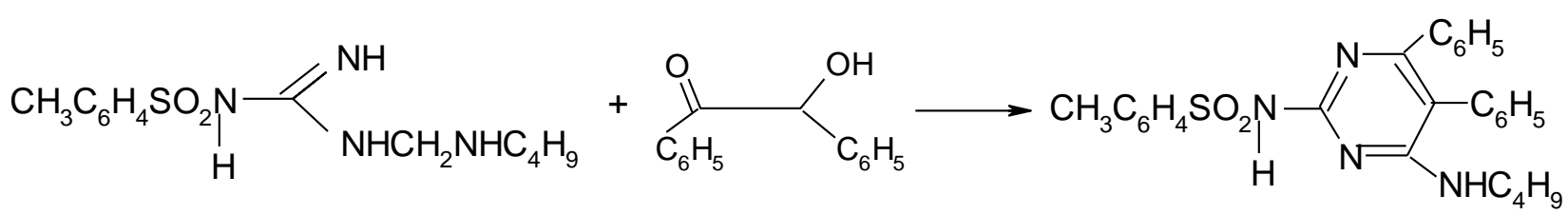

Compound Ic and Id with acetaceticethyl ether form pyrimidinons:<smiles>[R]CNC(=N)NOS(=O)(=O)c1ccccc1</smiles>

PMR-spectra (fig.2) of 2-N-butylaminomethyl4-methyl-(4-methylphenylsulfonamido)pyri-midone5 (IIe) showed that protons of methylene group of ntolyl, butyl fragment and pyrimidine appear in $0.9-$ $1.3 \mathrm{ppm}$, but protons of methylene group of butyl radical appear in $2.1-3.2 \mathrm{ppm}$. Proton of amino group of butyl radical is in $5.05 \mathrm{ppm}$, but proton of amino group of sulfamide appears in $6.1 \mathrm{ppm}$. Protons of methylene group $\mathrm{N}-\mathrm{CH}_{2}-\mathrm{N}$ appear in a weaker zone after aromatic fragment in $8.1 \mathrm{ppm}$, which confirms intensity of methylene group.

Our previous studies [11, 12] revealed high antimicrobial properties of sulfamide derivatives.
That's why synthesized compounds were tested as bactericides. Estimation of fungicide and bactericide properties of substances by GOST does not provide clear quantitative ranking of biocides on their activity due to the fact that in most cases antimicrobial effect can be fogged with low transportation rate of molecules to blocking receptors. Considering this circumstance, we used Hansh method for more complete characteristics of biocide properties of synthesized compounds of guanadinesulfamides and their heterocyclic derivatives [13].

This method is based upon the assumption on correlation between factors defining biochemical 


\begin{tabular}{|c|c|c|c|c|c|c|}
\hline Impact Factor: & $\begin{array}{l}\text { ISRA (India) } \\
\text { ISI (Dubai, UAB } \\
\text { GIF (Australia) } \\
\text { JIF }\end{array}$ & $\begin{array}{r}=1.344 \\
=0.829 \\
=0.564 \\
=1.500\end{array}$ & $\begin{array}{l}\text { SIS (USA) } \\
\text { PИHЦ (Russia) } \\
\text { ESJI (KZ) } \\
\text { SJIF (Morocco) }\end{array}$ & $\begin{array}{l}=0.912 \\
=0.234 \\
=1.042 \\
=2.031\end{array}$ & $\begin{array}{l}\text { ICV (Poland) } \\
\text { PIF (India) } \\
\text { IBI (India) }\end{array}$ & $\begin{array}{l}=6.630 \\
=1.940 \\
=4.260\end{array}$ \\
\hline
\end{tabular}

activity and physical-chemical parameters of substances.

Tests of synthesized compounds by Hansh method (estimation results of hydrophobic parameters, effective concentrations of preparations and other data) are given in table 1. Dependence laws of biological action speed on effective concentration with mixture of bacteria are shown in fig.3, but with mixture of fungi are given in fig. 4 .

Effect of synthesized compounds against fungi is distinguished by the fact that pyrimidine derivatives of guanidinesulfamides are more effective than functionally-substituted guanidines without heterocyclic fragment. Compounds (IIa), (IIb) and (IIe) are stronger fungicides than other compounds. It should be noted that pyrimidinesulfamides containing aminogroup are more effective than alkoxyderivatives. Among alkoxy- and aminomethyleneguanidinesulfamides compound (Ie) is more effective than compound (Ia), (Ib) and (Ic), and tangent of angle is lower: correspondingly $\operatorname{tg}_{28}=0.47, \quad \operatorname{tg}_{38}=0.65, \quad \operatorname{tg}_{53}=1.33$, $\operatorname{tg}_{44}=0.966$. This means that biological effect rate of compound (Ie) is higher than in compound (Ib).

From these facts important consequences follow for theory and practical developments of effective antimicrobial preparations: by direct variation of structure of potential inhibitors of biodeterioration, as well as by regulating with hydrophobic behavior and penetration into intracellular space of microorganisms we may achieve maximum value of effective concentration of preparation.

Results showed that all synthesized compounds have high ability to control vital functions of aerobic bacteria and mold fungi. They are more effective than industrial biocide «Sulfaxide». Rate of biological effect of compounds depends not on composition of heterocyclic fragment, but on nature of functional groups. As shown on figure 3 compound containing alkoxymethyl group is more effective than substances with aminomethyl group. Pyrimidinederivatives with butylamino group are more effective biocides than pyrimidine with alkoxy group. With increase of effective concentration in pyrimidinone containing alkoxy group (compound IId), rate of biological action sharply decreases. This means that this substance is more effective than other pyrimidines.

With decrease of biological action rate against bacteria and with increase of transport properties to intracellular space at low concentrations compounds can be arranged in the following order:

I $c>$ I $a>$ I b $>$ I d $>$ I g $>$ II a

Antimicrobial properties of alkoxy - and aminomethylenederivatives of guanidinesulfamides and

Table 3 pyrimidine by Hansh technique

\begin{tabular}{|c|c|c|c|c|c|c|c|c|c|}
\hline \multirow[b]{2}{*}{$\begin{array}{l}\text { Biocide } \\
\text { s and } \\
\text { compou } \\
\text { nds }\end{array}$} & \multirow[b]{2}{*}{$\begin{array}{l}\text { Distributi } \\
\text { on } \\
\text { coefficien } \\
t \text { of } \\
\text { octanol- } \\
\text { water, lg } \\
\text { Ps }\end{array}$} & \multirow[b]{2}{*}{$\begin{array}{c}\text { Hydroph } \\
\text { obic } \\
\text { parameter } \\
, \\
\delta\end{array}$} & \multirow[b]{2}{*}{$\begin{array}{c}\text { Steri } \\
\text { c } \\
\text { facto } \\
\text { r, } \\
\text { A }\end{array}$} & \multirow[b]{2}{*}{$\begin{array}{l}\text { Concentra } \\
\text { tion of } \\
\text { biocides } \\
\text { in } \\
\text { nutritive } \\
\text { medium, } \\
\mathrm{C}, \mathrm{mol} / \mathrm{l}\end{array}$} & \multirow[b]{2}{*}{$\begin{array}{c}\text { Effective } \\
\text { concentr } \\
\text { ation of } \\
\text { biocide, } \\
\mathrm{A} \cdot \mathrm{C} \\
\mathrm{mol} / \mathrm{l}\end{array}$} & \multicolumn{2}{|c|}{ Bacteria mixture } & \multicolumn{2}{|c|}{ Fungi mixture } \\
\hline & & & & & & $\begin{array}{c}\text { Absorptio } \\
\mathrm{n} \text { rate of } \\
\text { oxygen, } \\
\mathrm{W}_{\mathrm{O} 2} \\
\mathrm{~mol} / \mathrm{l} \cdot \mathrm{hr}\end{array}$ & $\begin{array}{c}\text { Rate of } \\
\text { biologic } \\
\text { al } \\
\text { action, } \\
\mathrm{K}_{\mathrm{p}} \cdot \mathrm{hr}^{-1}\end{array}$ & $\begin{array}{l}\text { Absorpt } \\
\text { ion rate } \\
\text { of } \\
\text { oxygen, } \\
\mathrm{W}_{\mathrm{O} 2} \\
\mathrm{~mol} / \mathrm{l} \cdot \mathrm{hr} \\
\end{array}$ & $\begin{array}{c}\text { Rate } \\
\text { of } \\
\text { biolog } \\
\text { ical } \\
\text { action, } \\
\mathrm{K}_{\mathrm{p}} \cdot \mathrm{hr}^{-1} \\
\end{array}$ \\
\hline 1 & 2 & 3 & 4 & 5 & 6 & 7 & 8 & 9 & 10 \\
\hline $\begin{array}{l}\text { Withou } \\
\mathrm{t} \\
\text { biocide }\end{array}$ & --- & --- & --- & --- & --- & 1.360 & --- & 0.970 & --- \\
\hline $\begin{array}{c}\text { Sulfaxi } \\
\text { de }\end{array}$ & $\begin{array}{l}3.98 \\
-/ /-\end{array}$ & $\begin{array}{l}1.18 \\
-/ /-\end{array}$ & $\begin{array}{c}0.201 \\
2 \\
-/ /- \\
\end{array}$ & $\begin{array}{l}18.6 \\
27.9\end{array}$ & $\begin{array}{l}3.74 \\
5.61\end{array}$ & $\begin{array}{l}0.763 \\
0.398\end{array}$ & $\begin{array}{l}0.744 \\
0.645\end{array}$ & $\begin{array}{l}0.446 \\
0.093\end{array}$ & $\begin{array}{l}0.146 \\
0.125\end{array}$ \\
\hline I a & $\begin{array}{l}3.27 \\
-/ /- \\
-/ /-\end{array}$ & $\begin{array}{l}2.49 \\
-/ /- \\
-/ /-\end{array}$ & $\begin{array}{c}0.212 \\
-/ /- \\
-/ /-\end{array}$ & $\begin{array}{c}5.57 \\
9.28 \\
18.56\end{array}$ & $\begin{array}{l}1.18 \\
1.97 \\
3.93\end{array}$ & $\begin{array}{c}0.326 \\
0.245 \\
0.05\end{array}$ & $\begin{array}{l}0.42 \\
0.38 \\
0.23\end{array}$ & $\begin{array}{l}0.82 \\
0.72 \\
0.41\end{array}$ & $\begin{array}{l}0.135 \\
0.119 \\
0.068\end{array}$ \\
\hline $\mathrm{Ib}$ & $\begin{array}{l}3.14 \\
-/ /- \\
-/ /-\end{array}$ & $\begin{array}{l}2.26 \\
-/ /- \\
-/ /-\end{array}$ & $\begin{array}{c}0.229 \\
-/ /- \\
-/ /-\end{array}$ & $\begin{array}{l}5.82 \\
9.72 \\
19.4\end{array}$ & $\begin{array}{l}1.33 \\
2.23 \\
4.38\end{array}$ & $\begin{array}{l}0.276 \\
0.245 \\
0.043\end{array}$ & $\begin{array}{l}0.40 \\
0.38 \\
0.34\end{array}$ & $\begin{array}{c}0.78 \\
0.66 \\
0.436\end{array}$ & $\begin{array}{l}0.129 \\
0.109 \\
0.072\end{array}$ \\
\hline I c & $\begin{array}{l}3.41 \\
-/ /- \\
-/ /-\end{array}$ & $\begin{array}{l}1.69 \\
-/ /- \\
-/ /-\end{array}$ & $\begin{array}{c}0.226 \\
-/ /- \\
-/ /-\end{array}$ & $\begin{array}{l}5.67 \\
9.47 \\
18.9\end{array}$ & $\begin{array}{l}1.28 \\
2.14 \\
4.27\end{array}$ & $\begin{array}{l}0.041 \\
0.039 \\
0.034\end{array}$ & $\begin{array}{l}0.31 \\
0.29 \\
0.19\end{array}$ & $\begin{array}{c}0.818 \\
0.72 \\
0.486\end{array}$ & $\begin{array}{c}0.135 \\
0.12 \\
0.081\end{array}$ \\
\hline
\end{tabular}

ISPC Education and Innovation, 


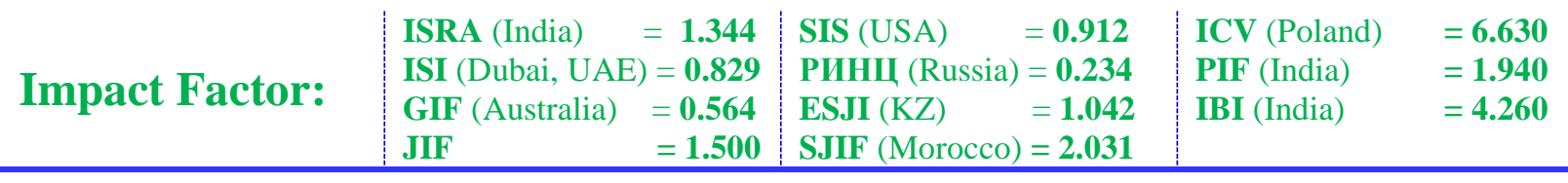

Continuation of table. 3

\begin{tabular}{|c|c|c|c|c|c|c|c|c|c|}
\hline 1 & 2 & 3 & 4 & 5 & 6 & 7 & 8 & 9 & 10 \\
\hline \multirow[t]{3}{*}{ I d } & 2.75 & 1.879 & 0.2011 & 5.92 & 1.191 & 0.65 & 0.67 & 0.192 & 0.082 \\
\hline & $-/ /-$ & $-/ /-$ & $-/ /-$ & 8.91 & 1.79 & 0.54 & 0.595 & 0.171 & 0.074 \\
\hline & $-/ /-$ & $-/ /-$ & $-/ /-$ & 17.8 & 3.58 & 0.39 & 0.46 & 0.122 & 0.052 \\
\hline \multirow[t]{3}{*}{$\mathrm{I} \mathrm{g}$} & 3.11 & 1.96 & 0.171 & 7.76 & 1.33 & 0.48 & 0.71 & 0.235 & 0.10 \\
\hline & $-/ /-$ & $-/ /-$ & $-/ /-$ & 11.63 & 1.99 & 0.42 & 0.68 & 0.216 & 0.092 \\
\hline & $-/ /-$ & $-/ /-$ & $-/ /-$ & 23.27 & 3.98 & 0.134 & 0.55 & 0.167 & 0.071 \\
\hline \multirow[t]{3}{*}{ II a } & 2.98 & 1.790 & 0.1965 & 7.83 & 1.54 & 0.69 & 0.74 & 0.199 & 0.085 \\
\hline & $-/ /-$ & $-/ /-$ & $-/ /-$ & 11.75 & 2.31 & 0.52 & 0.71 & 0.188 & 0.08 \\
\hline & $-/ /-$ & $-/ /-$ & $-/ /-$ & 23.50 & 4.62 & 0.46 & 0.66 & 0.150 & 0.064 \\
\hline \multirow[t]{3}{*}{ II d } & 3.21 & 1.91 & 0.1895 & 7.29 & 1.38 & 0.38 & 0.52 & 0.146 & 0.062 \\
\hline & $-/ /-$ & $-/ /-$ & $-/ /-$ & 10.93 & 2.07 & 0.19 & 0.41 & 0.138 & 0.050 \\
\hline & $-/ /-$ & $-/ /-$ & $-/ /-$ & 21.88 & 4.14 & 0.069 & 0.18 & 0.154 & 0.051 \\
\hline \multirow[t]{3}{*}{ II c } & 3.18 & 1.86 & 0.1911 & 7.51 & 1.435 & 0.691 & 0.76 & 0.168 & 0.072 \\
\hline & $-/ /-$ & $-/ /-$ & $-/ /-$ & 11.27 & 2.154 & 0.47 & 0.74 & 0.161 & 0.069 \\
\hline & $-/ /-$ & $-/ /-$ & $-/ /-$ & 22.54 & 4.30 & 0.44 & 0.60 & 0.145 & 0.059 \\
\hline
\end{tabular}

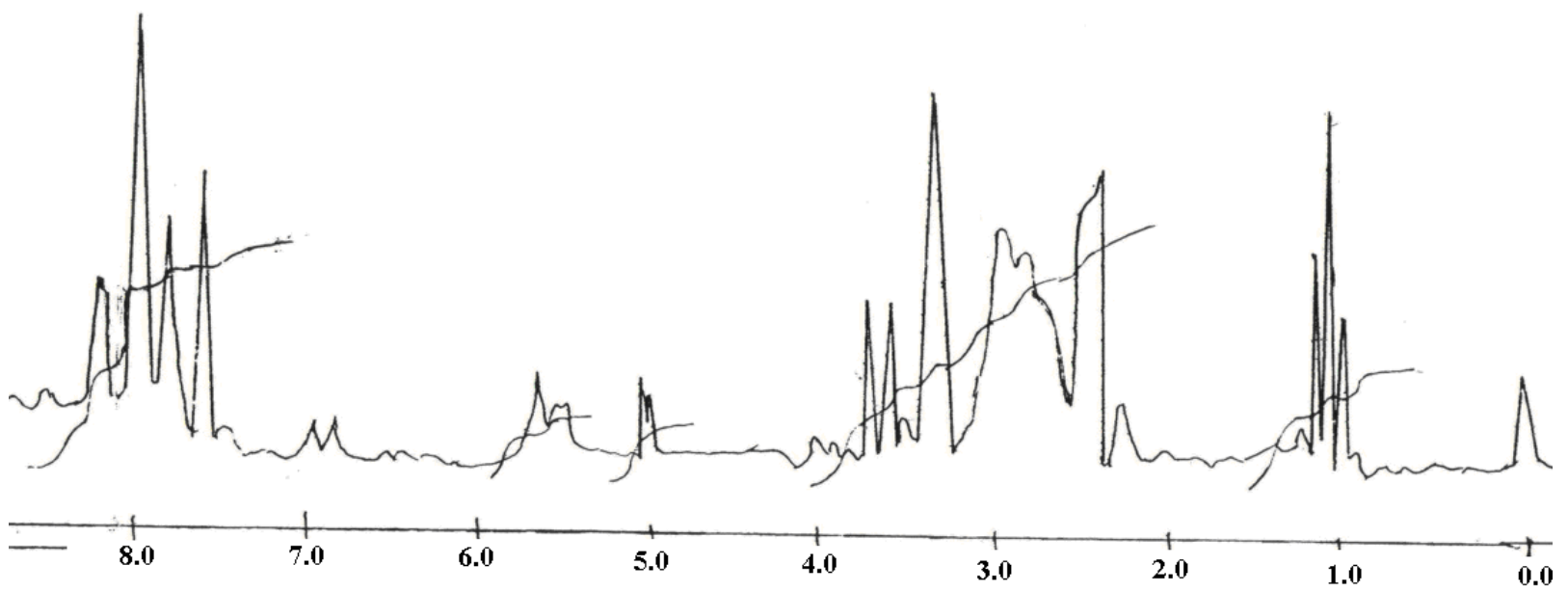

Fig.1 - PMR-spectra of 3-N-butylaminomethylene-4-methylphenylsulfanylguanidine (compound Id).

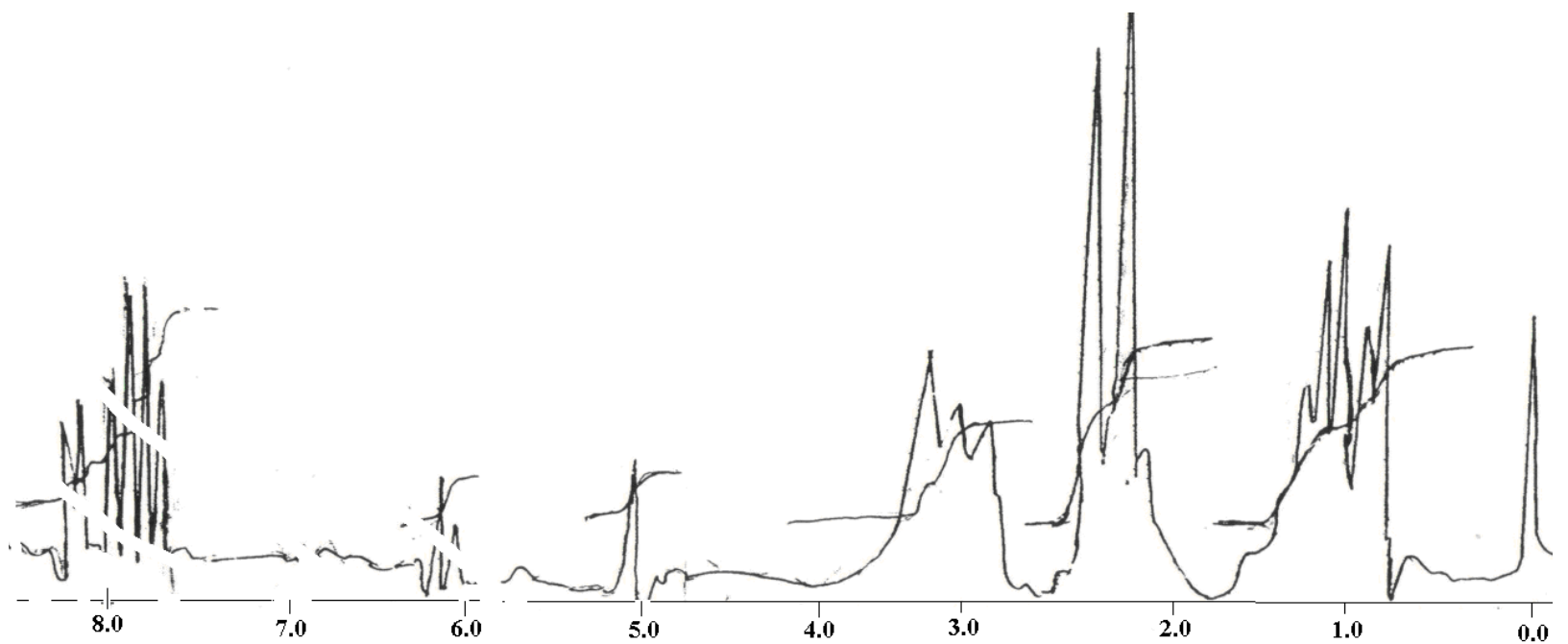

Fig.2 - PMR-spectra 2-N-butylaminomethyl-4-methyl-(4-methylphenylsulfonamide) pyrimidone-5 (compound IIe).

ISPC Education and Innovation, 


\begin{tabular}{l|lrl|l|ll} 
& ISRA (India) & $=\mathbf{1 . 3 4 4}$ & SIS (USA) & $=\mathbf{0 . 9 1 2}$ & ICV (Poland) & $=\mathbf{6 . 6 3 0}$ \\
Impact Factor: & ISI (Dubai, UAE) $=\mathbf{0 . 8 2 9}$ & PUHU (Russia) $=\mathbf{0 . 2 3 4}$ & PIF (India) & $=\mathbf{1 . 9 4 0}$ \\
& GIF (Australia) & $\mathbf{0 . 5 6 4}$ & ESJI (KZ) & $=\mathbf{1 . 0 4 2}$ & IBI (India) & $=\mathbf{4 . 2 6 0}$
\end{tabular}

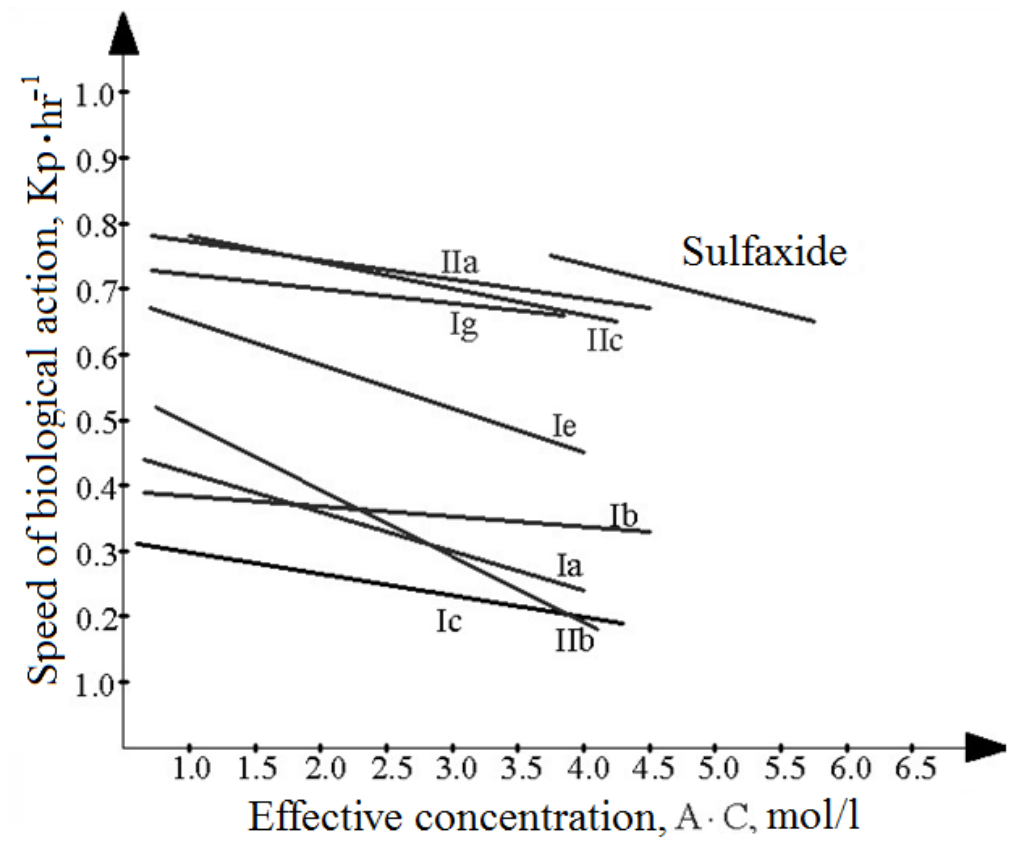

Fig.3 - Dependence of biological action speed on effective concentration with mixture of bacteria.

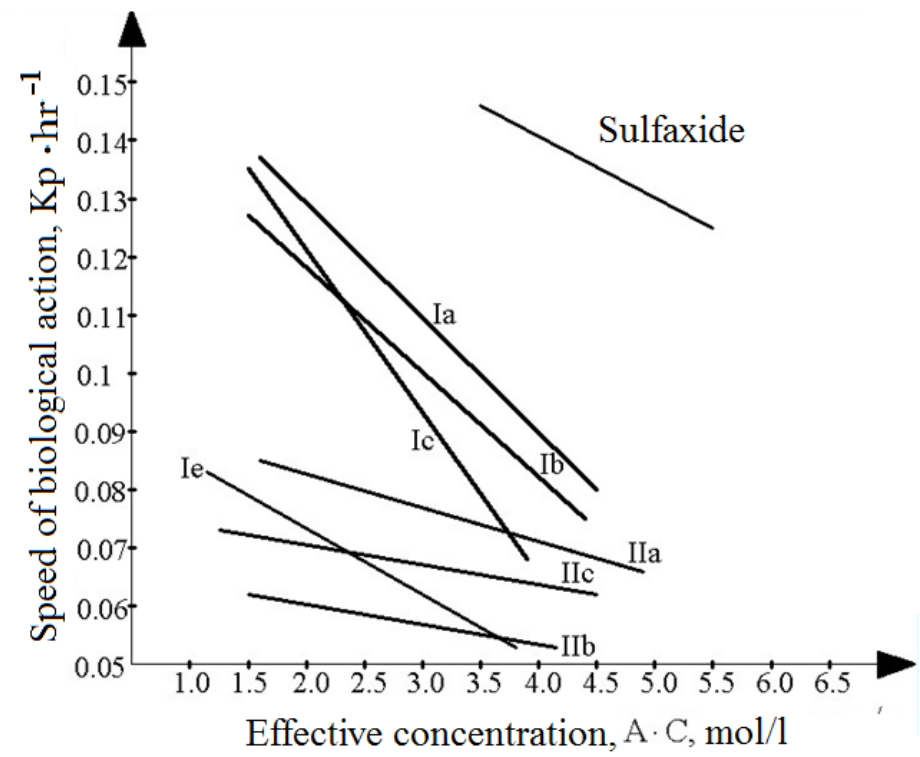

Fig.4 - Dependence of biological action speed on effective concentration with mixture of fungi.

\section{References:}

1. Gnieb H, Chien B, Gerlard M, et al. (2003) Sulfanylguanidines// Application 10112068 Germany. Application.12.08.11. Published.26.09.02. Chemical Abstract Journal 2003.09. $-190.90 \mathrm{H}$

2. Warch C, Bolm C (2007) Effective synthesis of sulfanilguanidines with sulfonilimidies with reactives of uronium // Synthesis. 2007. № 9. P.1355-1358. Chemical Abstract Journal 1980.07. 19.230

3. Lo Chi-yang, Zhang Hui-bin, Huating Wenlong, et al. (2008) Synthesis and hypoglycemic activity of sulfonaminothiourea and sulfonaminocyanoguanidine // J.China Pharm 


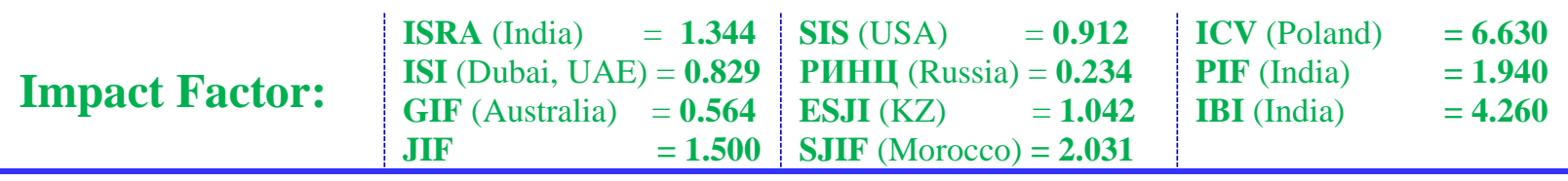

Unto. 2008. 39. № 1. P.7-11. Chemical Abstract Journal 2009.01. - 190.47

4. Sanofi-aventis DG, Kleeman HW (2008) Pentafluorosulfonylphenyl substituted benzoylguanidines, obtaining method, application as preparations or diagnostic agents and medical compositions // Patent. 7446226 USA. Application. 09.03.07. Published.04.11.08. Chemical Abstract Journal 2009.20. - 190.56P

5. Clemann KV (2008) Pentafluorosulfonylbenzoylguanidines, methods of their application and medical preparations // Patent. 2115752 Russia. Application. 05.05.2003. Published. 27.01.2008. Chemical Abstract Journal. 2008.13. - 190.45 P

6. Grunenthal GH, Chich B, Gerlack M, et al. (2002) Sulfinolguanidines// Application10048716 Germany. Application. 30.09.2000. Pulished.18.04.2002. Chemical Abstract Journal. 2003.07. - 190.93P

7. Grunenthal GH, Chich B, Gerlack M, et al. (2002) Sulfonylguanidine// Application10112068 Germany. Application. 12.09.2001. Published. 26.09.2002. Chemical Abstract Journal. 2003.19 - 190.90P

8. Mesheryakov VI, Daniyevich YS, Moskalik MY (2007) Triphamidemetylation of amides and sulfonamides// Journal of Organic Chemistry. 2007.43. № 6. p.799-805

9. Anaraki-Ardakani H, Noei M, Tabarzad A (2012) Simple synthesis of N-(arylsulfonyl)-4-
ethoxy-5-oxo-2,5-dihydro-1H-pyrrole-2,3dicarboxylates of one-pot three-component reaction // Chin.Chem.Lett. 2012. 23. № 1. P.45-48. Chemical Abstract Journal. 2012.08. 19.447

10. Ming-Juan, ShiMin (2007) Aza-reaction of Baylis-Hillman of salicyl-N-tosylamines with ethylvynilketon or phenylvynilketon // Tetrahedron. 2007. 63. № 42. P. 1041510424.Chemical Abstract Journal. 2009.02 19.210

11. Farzaliyev VM, Shahgeldiyeva LM, Mammadov SA, Ladokhina NP (2001) Arylsulfonylguanidines in synthesis of arylsulfonylpyrimidines// Azerbaijan Chemistry Journal. 2001. № 2. p. 20-22

12. Farzaliyev VM, Mammadov SA, Guliyev FA (2010) Correlation between chemical composition of sulfamides and their antimicrobial activity // Azerbaijan Chemistry Journal. 2010. № 4. p. 12-25.

13. (2006) Quantative Structure-Activity Relationships: Fundamental and Application of the Hansh Analysis «Practical Stutters for Medicinal Chemistry. An Integrating Approach for Developing Countries». IUPAC course. Educational and methodological materials on GSAR and medical chemistry. December 2006. p.54. 